\title{
Anti-CD20 monoclonal antibodies in Systemic Lupus Erythematosus
}

\author{
Kavina Shaha,* kavina.shah@ucl.ac.uk, Mark Craggb m.s.cragg@soton.ac.uk, Maria Leandroa \\ maria.leandro@ucl.ac.uk, Venkat Reddya v.reddy@ucl.ac.uk \\ aCentre for Rheumatology, University College London Division of Medicine, Rayne Building 4th Floor, \\ 5 University Street, London, WC1E 6JF, United Kingdom \\ ${ }^{\mathrm{b}}$ Centre for Cancer Immunology MP127, Southampton General Hospital, Tremona Road, \\ Southampton, SO16 6YD, United Kingdom \\ *Corresponding author.
}

\section{Keywords}

lupus; biologic; B cell therapy; anti-CD20 monoclonal antibody; rituximab

\begin{abstract}
Systemic Lupus Erythematosus (SLE) is an autoimmune inflammatory condition with a wide spectrum of disease manifestations and severities, resulting in significant morbidity and mortality. The aetiopathogenesis of SLE is complex. Young women and certain ethnicities are commonly affected, suggesting a significant hormonal and genetic influence. Diverse immunological abnormalities have been described. A characteristic abnormality is the presence of autoantibodies, implicating a central role for $\mathrm{B}$ cells in disease pathogenesis and/or perpetuation. Whilst conventional therapies have improved outcomes, a great unmet need remains. Recently, biological therapies are being explored. B-cell depletion therapy with rituximab has been in use off-label for nearly two decades. Inconsistent results between uncontrolled and controlled studies have raised doubts about its efficacy. In this review, we will focus on $\mathrm{B}$ cell abnormalities and the rationale behind B-cell depletion therapy with anti-CD20 monoclonal antibody (mAb), rituximab, will be explored including an evaluation of clinical and trial experience. Finally, we will discuss the mechanistic basis for considering alternative antiCD20 mAbs.
\end{abstract}

\section{Introduction}

Systemic Lupus Erythematosus (SLE) is an autoimmune inflammatory condition with a wide spectrum of disease manifestations and severities, resulting in significant morbidity and mortality (1). The etiopathogenesis of SLE is complex. Young women and certain ethnicities are commonly affected, suggesting a significant hormonal and genetic influence. Diverse immunological abnormalities have been described. A characteristic abnormality is the presence of autoantibodies, implicating a central role for B cells in disease pathogenesis and/or perpetuation. Whilst conventional therapies have improved outcomes, a great unmet need remains. Recently, biological therapies are being explored. B-cell depletion therapy with rituximab has been in use off-label for nearly two decades. Inconsistent results between uncontrolled and controlled studies have raised doubts about its efficacy. In this review, we will focus on B cell abnormalities and the rationale behind B-cell depletion therapy with anti-CD20 monoclonal antibody (mAb), rituximab, will be explored including an evaluation of clinical and trial experience. Finally, we will discuss the mechanistic basis for considering alternative anti-CD20 mAbs.

\section{Treatment of SLE}

\subsection{Conventional therapies and Refractory Disease}

Management of SLE largely depends on the organ involvement and the disease severity. Conventional therapy used routinely in the clinic to treat patients with SLE comprises of the 
immunomodulatory agent, hydroxychloroquine (HCQ) often in combination with steroids and an immunosuppressant such as mycophenolate mofetil (MMF), azathioprine (AZA), methotrexate (MTX) or cyclophosphamide (CYC), which are all steroid sparing and reduce disease flares (2).

Corticosteroids are frequently required to rapidly control a new flare of lupus, and at initial presentation, however the general consensus is to use the lowest dose possible for the shortest duration required in order to limit their adverse effects. Hydroxychloroquine is an anti-malarial drug with immunomodulatory properties, and has been proven to reduce mortality in lupus (3) and protect against renal damage in lupus nephritis (4). It is licensed in lupus and carries the benefit of not requiring blood monitoring, but requires ophthalmological screening for retinal toxicity.

The ALMS (Aspreva Lupus Management Study) demonstrated that oral MMF, a prodrug of mycophenolic acid, which reversibly inhibits inosine monophosphate dehydrogenase (5), was equivalent to intravenous $C Y C$ in treating both renal and non-renal manifestations of lupus nephritis (6) and superior to AZA (a prodrug to its active metabolic 6-mercaptopurine) for maintenance of remission in lupus nephritis (7). CYC, also used off license for SLE, is a precursor of an alkylating nitrogen mustard agent and inhibits nucleic acid synthesis to deplete lymphocytes and to a certain degree also macrophages (8). It is used for severe and organ/life-threatening lupus and almost always in the intravenous formulation, which carries less risk of bladder cancer than the oral preparation.

Calcineurin inhibitors ( $\mathrm{CNi}$ ) such as tacrolimus and ciclosporin have been used in lupus nephritis for many years as effective drugs to reduce proteinuria. A meta-analysis has demonstrated that tacrolimus (even more so when combined with MMF), was more effective than intravenous cyclophosphamide at achieving complete renal remission in lupus nephritis (9). More recently, voclosporin, a higher potency CNi without the need to measure drug levels, has filed for FDA approval for the indication of lupus nephritis following the successful AURORA study (10).

However, a significant proportion of patients does not respond to the conventional immunosuppressants discussed above and continue to accrue damage from active lupus (11) contributing to poor outcomes on quality of life, morbidity and survival. Here, we refer to active lupus not responding to conventional immunosuppressants as refractory disease. B-cell targeted therapies including Rituximab (unlicensed) were pioneered to treat patients with refractory SLE.

\subsection{B cell abnormalities in SLE}

Several B cell abnormalities have been described in SLE with a predominant role in contributing to the production of autoantibodies (12).

\subsubsection{Autoantibodies}

The pathogenesis of SLE is not fully understood. Immune dysregulation resulting in the development of autoantibodies is a hallmark of the condition, with over $95 \%$ of patients having autoantibodies against nuclear antigens (ANA)(13). The heterogeneity of the condition is associated with the range of extractable nuclear antigens (ENA) including Ro, La, RNP and Sm, as well as associated antiphospholipid antibodies, which are associated with thrombosis and pregnancy related complications. Anti-double stranded DNA (dsDNA) antibodies, were identified in 1967 from renal biopsies of patients with lupus nephritis (14), found to be highly specific for SLE, present in $70 \%$ of patients (and only $<0.5 \%$ of those without SLE)(15) and are therefore implicated in the pathogenesis of SLE (16). Rising anti-dsDNA antibodies and reciprocal changes in serum complement C3 and C4 levels, can indicate a lupus flare and levels correlate with treatment response and are therefore considered relevant outcome measurements in routine clinical practice (17) and clinical trials. Collectively, these findings implicate an important role for B cells in the pathogenesis of SLE.

\subsubsection{Autoreactive B cells}

Autoreactive B cells are defined as B cells reactive against self-antigens. In health, the development of autoreactive B cells is effectively censored. However, when certain checkpoints fail, 
an increased number of autoreactive B cells survive and contribute to autoimmunity, (18), illustrated in Figure 1. In SLE, nearly double the amount of autoreactive mature naïve $B$ cells were identified by Yurasov et al when compared to healthy individuals as well as an increased number of polyreactive antibodies (19). Various mechanisms of evading checkpoints through defective B-cell tolerance have been identified in patients with SLE, including the expression of the 9G4 idiotype on autoreactive B cells (20), (21) and by the FasL pathway through CD95 expression (22). Defective clearance of apoptotic debris and the abundance of self-antigens provide the source of autoantigens to sustain autoreactivity (23). Further, higher levels of BAFF (B lymphocyte Activating Factor of the tumour necrosis factor Family) and type I IFN may promote the survival of autoreactive B cells (24). Thus, autoreactive $B$ cells are a key feature of SLE.

In accord with the presence and alterations in autoantibodies with disease activity, patients with SLE have a greater frequency of activated memory B cells in peripheral circulation, as defined by the relative expression of the cell surface markers IgD-CD27-CD95+ and CD27 (high) plasma cells when compared with healthy individuals (25). The frequency of CD27(high) plasma cells has also been found to correlate with disease activity and response to treatment. Therefore, B-cell depletion therapy was pioneered for refractory SLE (26).

\subsection{B-cell and other targeted Therapies}

There is ongoing research in the field of SLE treatments with biologic therapies to target various pathways in the SLE immunopathogenesis. A large focus of this has been on B cells as they are so crucially implicated in lupus, and we discuss the various B cell targeted therapies below.

\subsubsection{Anti-BAFF, Belimumab}

Belimumab is a recombinant fully human IgG1 monoclonal antibody against the soluble cytokine BAFF, also termed BLyS (B lymphocyte stimulator). It is the only licensed biologic agent for treatment of active (non-renal, non-central nervous system, CNS) lupus, refractory to conventional therapy (27), following two successful randomised controlled clinical trials: BLISS-52, $n=867,(28)$ and BLISS-76, $\mathrm{n}=819$ (29), which both achieved their primary efficacy endpoints, respectively $14 \%$ and $10 \%$ higher SLE-responder index (SRI) rates with Belimumab $10 \mathrm{mg} / \mathrm{kg}$ compared to placebo at week 52 . The most marked improvement was found in mucocutaneous, musculoskeletal and immunological (reduction in anti-dsDNA antibodies, improved C3 and C4 levels) domains. Belimumab reduces BAFF-dependent survival of autoimmune $B$ cells including plasma cells and limits $B$ cell-driven autoimmunity, with a reduction in anti-dsDNA antibodies. The positive outcomes of these trials further implicate B cells in the development and disease progression of lupus. However, patients with active renal or CNS manifestations were excluded from entering the trials and, possibly reflecting this, only a small proportion of patients $(<10 \%)$ had prior MMF treatment in the phase III studies.

\subsubsection{Anti-BAFF/APRIL}

Atacicept and telitacicept inhibit both BAFF and APRIL (A PRoliferation-Inducing Ligand), another cytokine which has been identified as an important B-cell regulator. High levels of these cytokines have been found to correlate with disease activity and antibody production in lupus (30). Patients with active SLE who received telitacicept as part of a phase $2 \mathrm{~b}$ trial achieved $40 \%$ higher SRI4 (SLE Responder Index4) response rates compared to placebo and it was also reported to be well tolerated (31).

\subsubsection{Anti-interferon therapies}


Previous studies have shown that elevated interferon-alpha correlates with SLE disease activity (32). Both sifalimumab (anti interferon-alpha $\mathrm{mAb}$ ) and anifrolumab (mAb that binds to a type I interferon receptor) have shown beneficial results in phase II randomised control trials versus standard of care plus placebo in patients with moderate-severe, non-renal, non-CNS SLE (33), (34). TULIP-2, a phase III trial of anifrolumab demonstrated superiority compared to placebo in patients with active SLE with regards to improved BICLA (British Isles Lupus Assessment Group (BILAG)based Composite Lupus Assessment) response, as well as reduction in corticosteroid dose and improvement in skin disease (35). Patients with active severe lupus nephritis or neuropsychiatric lupus were excluded. Therefore, as yet there is little evidence of the use of anti-interferon therapies in severe refractory disease affecting vital organs, where B-cell depletion therapy using the anti-CD20 monoclonal antibody, rituximab, was pioneered before the availability of Belimumab and antiinterferon therapies.

Aside from CD20, other B cell targeting mAbs, which have been considered in SLE treatment include $C D 22, C D 19, C D 32 b$ and they each have varying effects on B cells. Further discussion about these options is beyond the scope of this review; hence we will limit the discussion to B-cell depletion therapy with anti-CD20 mAbs.

\subsection{Anti-CD20 monoclonal antibody-induced B-cell depletion therapy}

\subsubsection{Clinical experience in SLE}

Following the license of rituximab, a chimeric anti-CD20 monoclonal antibody, with human IgG1 and kappa constant regions and of mouse variable regions, for follicular lymphoma in 1997/8, Professor Edward's group at UCL reported its efficacy and safety in rheumatoid arthritis (RA) (36) which formed the basis of randomised controlled trials (37) leading to its current licence for RA. The first published open label study of B cell depletion therapy using Rituximab, in 6 female patients with active SLE reported its evidence for safety and efficacy (38). Patients received two $500 \mathrm{mg}$ rituximab infusions and two $750 \mathrm{mg}$ intravenous cyclophosphamide doses, together with prednisolone $30 \mathrm{mg}$ or $60 \mathrm{mg}$ for 5 days. The treatment protocol was based on the group's experience in RA. Disease activity according to BILAG scores (39) and laboratory markers including haemoglobin, erythrocyte sedimentation rate, urine protein:creatinine and C3 levels had markedly improved at 6 months follow up. Repeated treatment as per clinical need with rituximab was found to be safe and resulted in a more sustained response, with greater remission rates following cycle 2 which was maintained at 12 months: $65 \%$ after cycle 2 versus $39 \%$ after the first cycle (40). Other groups also reported positive results as described below (41)(42)(43).

A systematic review of the off-label use of rituximab in 188 cases of refractory SLE from case reports and open studies was published, with $91 \%$ demonstrating a significant improvement in one or more SLE manifestations, and $23 \%$ of patients reporting adverse effects, of which the majority were infections (44). Registry data reported a $67 \%$ partial or complete response to rituximab in 164 patients with refractory or relapsing biopsy proven lupus nephritis (45). Based on this consistent clinical experience the safety and efficacy of rituximab in renal and non-renal refractory lupus was tested in clinical trials.

\subsubsection{Trial experience}

Two phase III randomised placebo controlled trials (RCT) investigating the safety and efficacy of rituximab in moderately active non-renal SLE (EXPLORER) and in lupus nephritis (LUNAR) have been published.

In the EXPLORER trial (46), 257 patients with $\geq 1$ BILAG A score or $\geq 2$ BILAG B scores (largely musculoskeletal and mucocutaneous manifestations) despite immunosuppression with azathioprine, mycophenolate or methotrexate (continued throughout the study) were randomised 2:1 to receive 
rituximab (2x1000mg infusions given 14 days apart) or placebo on days $1,15,168$ and 182 . After screening, patients commenced additional oral corticosteroids (prednisolone $0.5 \mathrm{mg} / \mathrm{kg}, 0.75 \mathrm{mg} / \mathrm{kg}$ or $1.0 \mathrm{mg} / \mathrm{kg}$ according to disease activity reflected in their BILAG score), which were tapered from day 16. More than half (57\%) of the study population was categorised as being steroid dependent and $\geq$ $60 \%$ received an average $45.9 \pm 16.4 \mathrm{mg}$ prednisolone and then attempted to reduce to a target dose of $<10 \mathrm{mg} /$ day over the 10 week taper period and $\leq 5 \mathrm{mg} /$ day at week 52 . The primary end point was assessed at 52 weeks using the BILAG index to achieving and maintaining either a major or partial response based on the loss of BILAG A and B scores.

The trial did not identify any differences between the addition of placebo or rituximab to standard of care in both primary and secondary efficacy end points, including the BILAG-defined response. There was an observed beneficial effect of rituximab on the primary end point in the African American and Hispanic subgroups, with a major clinical response in $13.8 \%$ and a partial response in $20 \%$ (compared to $9.4 \%$ and $6 \%$ respectively). This subgroup had more active and refractory disease, as previously described (47). The study did however confirm good safety and tolerability of rituximab as compared to placebo and serological markers did improve following treatment with rituximab, including greater fall in anti-dsDNA levels and rise in complement levels compared with placebo.

The LUNAR study (48) enrolled 144 patients with class III and IV proliferative lupus nephritis in addition to high dose corticosteroid therapy and MMF $3 \mathrm{~g} /$ day, randomised 1:1 to receive rituximab or placebo with the same regimen as the EXPLORER study. The primary efficacy end point was the proportion of patients with complete or partial renal response at week 52. If neither complete or partial response criteria were met, early termination from the study or inability to assess the end point due to missing data, then patients were categorised as non-responders. The secondary endpoints included complete renal response sustained from week 24 to week 52; time to first complete renal response; and, improvement of urine protein-to-creatinine ratio from $>3$ to $<1$ at week 52 , the time-adjusted area under the curve minus the BILAG global score, and a change in the physical function of SF-36 health survey. Serological markers were also monitored as in the EXPLORER study.

In the rituximab treated group, $26 \%$ achieved complete and $30 \%$ achieved partial renal remission, compared to the placebo-control group who achieved $30 \%$ and $15 \%$ respectively. The absolute difference between the rituximab and placebo treated groups was $11 \%$, and this value was less than the planned $23 \%$ difference, therefore making this a negative study. It is important to note that the true time taken to remission of proteinuria is usually up to two years, and therefore when assessed in the trial, this outcome measure was prematurely recorded as a non-response. A two year follow up period and more realistic efficacy difference would have seen a different outcome and end-points would have been achieved even with this conservative sample size.

LUNAR was powered to detect a difference in complete response rates, and underpowered to detect a difference in partial response rates which were higher in the rituximab treated group. It is important to note that 8 versus 0 patients in the placebo group required rescue cyclophosphamide therapy and average corticosteroid requirement was lower in the rituximab arm. Proteinuria improved by $32 \%$ in the rituximab group versus $9 \%$ in the placebo group. As noted in the EXPLORER study, there was a trend for a greater number of black patients responded favourably to rituximab (although not statistically significant), and rituximab treated patients exhibited greater improvement in serological markers of activity (C3 and anti-dsDNA). Safety data was comparable between placebo and rituximab groups, but interestingly serious adverse events were more common in the placebo arm. Therefore, it is important to understand why the two major trials of rituximab in lupus were unsuccessful toward improving clinical response and outcomes.

\subsection{Understanding the variability in clinical and biological response}

The various confounding factors, which may have contributed to the apparent inefficacy of rituximab in clinical trials, as outlined Table 3. Broadly, two sets of factors: clinical trial design or biological mechanisms of resistance to rituximab.

\subsubsection{Impact of Clinical Trial Design}


Several factors in clinical trial design may have contributed to the unexpected outcomes, which have been reviewed previously (49). Firstly, the background immunosuppression, particularly high dose corticosteroids and MMF are effective in a significant proportion of patients, and therefore superiority of rituximab was likely to be difficult to demonstrate. Whereas in ANCA-associated vasculitis, the design was a non-inferiority trial and it was a positive trial (50). Secondly, the response criteria were stringent and response even in vital organ manifestations with a flare in a non-vital organ system constituted as failure. Thirdly, the relatively short duration of the trials may not have allowed for improvements to capture, such as reduction in proteinuria, which may take longer time period to detect. Finally, in contrast to uncontrolled studies RCTs may have excluded patients with major organ involvement such as the brain and previous use of cyclosporine and/or cyclophosphamide, where rituximab was reported to be effective. There are many lessons to be learnt for future clinical trial design especially in such a diverse condition such as SLE. Regardless, biological reasons for failure may also have contributed to the apparent inefficacy.

Amongst several biological reasons for the negative results, a critical logical factor is the failure to induce complete B-cell depletion, which can be associated with poor or no clinical response (51).

\subsection{Resistance driven-development of anti-CD20mAbs (bench-bed-bench)}

The response to rituximab in SLE is not uniform, and considerable variability exists with regards to extent of B-cell depletion, duration of B-cell depletion and time to subsequent clinical flare following initial response and these differences have driven research into optimising anti-CD20 therapies.

\subsubsection{Incomplete B-cell depletion: a key resistance mechanism}

There is conflicting data with regards to the degree of depletion correlating with clinical response or not. For example, an open label study demonstrated correlation (43), while the randomised clinical trial in non-renal lupus, EXPLORER, failed to confirm this relationship (46). A large retrospective review of 115 patients treated with rituximab in a single centre, demonstrated that longer periods $(>12$ months) of B cell depletion were associated with improved clinical response (52). The two RCTs (EXPLORER and LUNAR) found no impact of B-cell depletion, defined as a threshold of $<10 \mathrm{cells} / \mathrm{\mu l}$, and clinical response to rituximab (46) whereas Vital et al. using highly sensitive flow cytometry with stringent detection of $B$ cells with a threshold $<5$ cells $/ \mu$ l, found that none of the patients that did not respond had depleted completely (51). To note, repopulation of plasmablasts and to an extent memory B cells at 26 weeks post rituximab treatment was faster in patients with earlier relapse of disease, which is clinically important as a potential biomarker of relapse (51). Therefore, arbitrary thresholds for the definition of B-cell depletion, differences between cohorts and clinical manifestations and severity and background therapies may all contribute to the apparent discrepancy in reported clinical response between uncontrolled and controlled studies (49). Incomplete B-cell depletion may be related to lower serum rituximab levels, the development of human anti-chimeric antibodies (HACAs) and internalisation of rituximab among other factors.

\subsubsection{Human anti-chimeric antibodies (HACAs)}

In a phase I/II dose escalation trial of rituximab in SLE, HACAs were demonstrated in 6 of 17 patients particularly in those with African descent, higher pre-treatment disease activity and lower rituximab doses and serum HACA titres were associated with incomplete B-cell depletion (42). However, another study did not show a strong overall correlation between HACAs and the extent of B-cell depletion, as some patients had low level HACA but achieved complete B-cell depletion (43). In the phase III EXPLORER trial, a quarter of patients developed HACAs, but an impact on clinical outcomes was not identified (46). Hence, B-cell depletion with humanised anti-CD20 mAbs including Ocrelizumab and Ofatumumab has been explored as alternative B-cell depleting agents.

\subsubsection{Ocrelizumab}


Ocrelizumab, a humanised anti-CD20 mAb was investigated in a placebo-controlled trial in lupus nephritis (53)]. Ocreclizumab doses were, $400 \mathrm{mg}$ or $1000 \mathrm{mg}$ given at day 1 and day 15 , followed by a single infusion every four months, with continued conventional therapy of corticosteroids and MMF or CYC (following the EUROLUPUS dosing regimen). The trial was stopped prematurely due to an increased incidence of serious infections in the ocrelizumab arm, more in the MMF combination and with higher doses of ocrelizumab, compared to placebo. Combining the ocrelizumab groups versus placebo, demonstrated a $12 \%$ difference in renal response rates with $63 \%$ and $51 \%$ respectively. This difference was identified in patients receiving cyclophosphamide co-therapy, but not MMF. However, as in the LUNAR study with rituximab this may be explained by an augmented response rate with MMF treatment regardless of combination with $B$ cell depleting agents. Ocrelizumab has been approved for use in multiple sclerosis - in both relapsing and primary progressive forms of disease and has shown to have higher efficacy than interferon $\beta-1$ a (54).

\subsubsection{Ofatumumab}

Ofatumumab, a human anti-CD20 IgG1 mAb has been shown to be effective in a patient with suspected serum sickness and anaphylaxis triggered by rituximab (55). Recently, Yusof et al. reported a small number of patients with $\operatorname{SLE}(n=5)$ who had incomplete B-cell depletion with rituximab and had developed HACAs, who achieved B-cell depletion and response following treatment with humanised antibodies Ocrelizumab or Ofatumumab (56). Thus, humanised mAbs offer an alternative to some patients with SLE with rituximab-induced HACAs. However, alternative resistance mechanisms explored previously may provide insights into how B-cell depletion therapy may be further improved in SLE. Ofatumumab has been approved for use in chronic lymphocytic leukaemia (57) as well as recent approval for patients with multiple sclerosis (58).

\subsubsection{Serum rituximab levels}

It is not possible to directly extrapolate the experience of serum rituximab levels from malignancy to autoimmune disease owing to differences in target cell number, tumour size and dosing regimens. Further, lupus nephritis with proteinuria may potentially reduce serum rituximab levels. Studies in Non-Hodgkin's Lymphoma noted a median serum rituximab concentration of $25.4 \mu \mathrm{g} / \mathrm{mL}$ in good responders, compared to $5.9 \mu \mathrm{g} / \mathrm{mL}$ in non-responders (59). In chronic lymphocytic leukaemia (CLL), very low concentrations $(<1 \mu \mathrm{g} / \mathrm{mL})$ were observed 1 week after treatment with rituximab $375 \mathrm{mg} / \mathrm{m} 2$ (60) whereas after subsequent infusions, the half-life of rituximab was estimated at $18 \pm 15$ (mean \pm SD) days (61). In CLL, a higher dosing regimen (62), a higher serum rituximab levels before the third infusion, and in combination with chemotherapy was associated with better response (63). However, in RA, variability in B-cell depletion occurred regardless of the dose used (64) and incomplete depletion and associated poor response was improved by an extra dose of rituximab (65).

Anolik and colleagues in the phase I/II trial studied rituximab levels in lupus patients treated with low, medium and high doses which translated to $100 \mathrm{mg} / \mathrm{m} 2$ single infusion, $375 \mathrm{mg} / \mathrm{m} 2$ single infusion and four doses of $375 \mathrm{mg} / \mathrm{m} 2$ given a week apart, with 2 month serum levels of rituximab: $<0.02-4.8$ $\mu \mathrm{g} / \mathrm{mL} ;<0.02-7.8 \mu \mathrm{g} / \mathrm{mL}$; and $0.36-22.5 \mu \mathrm{g} / \mathrm{mL}$ respectively. B-cell depletion was defined as CD19+ cell $<5$ cells $/ \mu \mathrm{L}$ and patients who achieved this had greater mean serum rituximab levels 2 months post initial treatment with median serum rituximab levels of $1 \mu \mathrm{g} / \mathrm{mL}$ independent of the FcyRIlla type (41). The UCL group has also clearly demonstrated that even in a small number of patients serum rituximab levels were significantly lower in patients with SLE when compared with RA (66). Thus, serum rituximab levels seem to vary in different histological malignancies and autoimmune diseases and dosing regimens used. Therefore, disease-associated altered metabolism of IgG may also significantly reduce the half-life of rituximab in SLE (67). Collectively, these studies suggest the host immune system significantly impacts on the efficiency of rituximab. 
The phase I trial of chimeric anti-CD20 mAb in 15 patients with recurrent B cell lymphoma two weeks after treatment, histological examination of the tumour demonstrated rituximab bound to tumour cells, which indicates that despite binding to B cells, rituximab did not remove these malignant cells (68). Lymph node B cells, not necessarily tumour cells, can be coated with anti-CD20mAbs but are not always depleted. This introduces the two important concepts of access to the drug, but also local efficiency of depletion mechanisms and cellular resistance to rituximab, which needs further investigation.

B-cells in lymphoid tissues were less efficiently depleted in individuals who received a single $500 \mathrm{mg}$ dose of rituximab prior to organ transplantation (69) (70). Thus, the location of B cells also impacts on B-cell depletion.

\subsubsection{CD20 expression}

The intensity of CD20 expression on malignant B cells from different histological types is significantly variable. For example, in CLL, CD20 expression is low (71) and corresponding outcomes following rituximab are inferior compared to follicular lymphoma (FL), where CD20 expression is higher. However, despite greater CD20 expression than in CLL, clinical response to rituximab in mantle cell lymphoma is surprisingly poor (72). Therefore, CD20 expression alone does not fully explain the differing extents of B-cell depletion, as some B cells are not depleted despite being bound by rituximab (73). An intriguing proposed mechanism of resistance to rituximab is internalisation of CD20:rituximab complexes (74).

\subsubsection{Internalisation of $C D 20$}

Professor Cragg and Glennie's team demonstrated that malignant B cells internalised CD20:antiCD20 mAbs complexes, thereby, reducing the efficiency of depletion predominantly by limiting engagement of immune effector cells and increasing mAb consumption (74). This process seems to be controlled by the inhibitory FcyRllb which is differentially expressed on B cells according to histological type of malignancy, with lower expression in FL, correlating with better B-cell depletion with rituximab, compared to CLL which had poorer outcomes following rituximab (75). Despite FcyRllb 232 isoleucine/threonine polymorphisms not predicting response to clinical response rituximab in FL, (76), expression of the inhibitory FcyRIlb on FL, was able to predict response to rituximab, with enhanced responses in those expressing less FcyRIlb as in the previous study (77). Therefore, internalisation of CD20 seems to be an important resistance mechanism to rituximab in B cell malignancies. To understand why internalisation is a feature of some, but not all, anti-CD20 mAbs, we will now discuss the biology of CD20 and its interaction with anti-CD20 mAbs.

The purpose of rituximab therapy is to mediate $B$ cell deletion through the engagement of immune effector systems dependent upon the Fc portion of the mAb. However, trogocytosis of the target antigen via an immunologic synapse has been suggested to impair B-cell depletion by anti-CD20 mAbs. In trogocytosis, the effector cell removes the RTX-CD20 immune complex, preventing Fcmediated effector functions. This has been described in B-cell malignancies (78), and in rheumatoid arthritis (79), but its importance has yet to be clearly validated (80).

\subsection{Type I and II anti-CD20 mAbs}

\subsubsection{CD20 expression through B cell differentiation}

B cells are generated in the bone marrow from haematopoietic stem cells and undergo further maturation, activation and differentiation in secondary lymphoid tissues (81). Using flow cytometry it is possible to detect a range of $\mathrm{B}$-cell subpopulations, distinguished by relative expression of key cell surface markers including surface immunoglobulin isotypes (BCR) as detailed in Table 1 . The early phase of $B$ cell maturation takes place in the bone marrow: pro-B cells, pre-B cells and immature $B$ cells. Transitional $B$ cells migrate from the bone marrow into secondary lymphoid tissues, where the 
latter phase of development is dependent on encounter with specific antigens. In peripheral blood, naïve, mature and memory B cells together with smaller numbers of plasma blasts and particularly plasma cells, are observed, with the latter found predominantly in secondary lymphoid organs and bone marrow.

As depicted in Figure 1 and Table 1, CD20 is expressed on most stages of B cell development, from pre-B to memory B-cells, but is lost upon differentiation into antibody secreting plasma cells. Therefore, plasma cells are not directly depleted by anti-CD20 therapy.

\subsubsection{Cells that express $C D 20$}

Despite CD20 principally being a pan marker used to identify B lymphocytes, there is some evidence to suggest this is not exclusive as some T lymphocytes (82), and NK cells express low levels of CD20 (CD56+CD3-CD20low). Therefore, these cells were also not detectable at 1 month after treatment with Rituximab in patients with RA (83). Furthermore, the levels of CD20 expression on $B$ cells varies according to the stage of differentiation.

\subsubsection{CD20 as a B-cell target antigen}

In 1980, Stashenko et al. first discovered CD20, originally described it as 'B lymphocyte-specific antigen', B1, They noted that removal of the B1 positive population in peripheral blood, depleted cells with the potential to differentiate into plasma cells (84). CD20 is encoded by the MS4A1 gene, part of the membrane-spanning 4-A gene family (85), which encodes a 33-37 kilodalton, non-glycosylated phosphoprotein expressed during $B$ cell differentiation from the pre-B cell until plasma cell stage when it is lost (for more detail see below), suggesting a potential role for CD20 in cell-cycle regulation (86). A young patient with CD20 deficiency due to a homozygous mutation in a splice junction of the MS4A1 gene was found to have reduced numbers of IgD-CD27+ memory B cells. This resulted in impaired T-cell independent antibody responses, supported by studies in CD20 deficient mice (87). Thus, CD20 seems to play an important role in influencing B cell function.

As illustrated in Figure 2, CD20 crosses the cell membrane four times with a small and large extracellular loop with both amino and carboxy termini located intracellularly (85). CD20 exists predominantly as a tetramer on the cell surface (88) and when some anti-CD20 mAbs bind, they induce translocation of CD20 into lipid microdomains, also known as lipid rafts, located in the plasma membrane, associating with the B cell receptor (88) (89) and influence calcium influx and downstream signaling (90). CD20 is highly expressed by over $95 \%$ of normal and malignant B cells and therefore was targeted by mAbs to deplete B cells, particularly because it was initially believed not to be shed or internalised from the cell membrane (91).

One of the first anti-CD20 mAbs to be produced was 2B8 or IDEC-2B8, a high affinity murine antibody, generated by immunising mice with lymphoma cells expressing CD20 (84). Following insertion of the $2 \mathrm{~B} 8 \mathrm{~V}$ regions into a cDNA vector containing human IgG1 heavy chain and human kappa-light chain constant regions, Chinese hamster ovary cells were transfected and selected to produce high levels of chimeric-2B8 antibody (68). This mAb was able to bind human CD20 and mediate $\mathrm{C} 1 \mathrm{q}$ and $\mathrm{Fc}$ gamma receptor (FcgR) binding leading to the cytotoxicity and deletion of human B-lymphoid cells which informed the future clinical trials.

As summarised in figure 3 , anti-CD20 mAbs can deplete B cells by four distinct effector mechanisms (72) (92). These may be FcgR-mediated, which include antibody-dependent cellular cytotoxicity (ADCC) and antibody-dependent cell phagocytosis (ADCP), and FcgR-independent effector mechanisms, which include direct cell death (DCD) and complement-dependent cellular cytotoxicity (CDC). Although the relevance of each mechanism to efficient B-cell depletion in vivo and at different locations in different disease states is less clear there is now greater understanding of the characteristics of different mAbs and their effector mechanisms

\subsubsection{Anti-CD20 mAbs}


To overcome the resistance to rituximab, alternative anti-CD20 mAbs with unique characteristics have been developed. Mechanistically, anti-CD20 mAbs can be classified as type I or type II. For example, obinutuzumab, a type II anti-CD20 mAb, is licensed for rituximab-refractory B cell malignancies and is currently undergoing a phase II study in lupus nephritis and is the only type II $\mathrm{mAb}$ to be have entered clinical trials in SLE (93). The differences between these two types of mAb are described below.

The categorisation of anti-CD20 mAbs into type I and type II stems from their structure (Figure 2) and post-binding characteristics. Consequently, their effector mechanisms are altered as outlined in Tables 2 and Figure 3. Type I anti-CD20 mAbs have a greater ability to redistribute CD20 tetramers into lipid rafts compared to type II, and this enables them to efficiently recruit complement to induce CDC (94). However, the clustered CD20:type I-CD20-mAb complexes are more prone to internalisation by $B$ cells, a process regulated by the inhibitory FcgRIlb [68], which likely reduces their overall efficacy (74) (95) (96). In contrast, type II mAb neither internalise rapidly, nor evoke efficient CDC.

As demonstrated in Figure 2, type I and type II mAbs bind CD20 at overlapping but subtly different sites. This molecular difference of rituximab binding to asparagine 171 , which is $\mathrm{N}$-terminally located and central to the interaction interface, and obinutuzumab binding to asparagine176, which is carboxyterminally located (97), presumably accounts for their differing abilities to redistribute CD20 into lipid rafts. The peripheral binding interface of obinutuzumab places a steric constraint on the conformation of the large extracellular loop of CD20, and this may elicit a preference for certain CD20 orientations or subpopulations. As such, type II mAbs bind half the number of CD20 molecules compared to type I, which could reflect binding to different subpopulations of CD20 (98). In support of this suggestion, $x$-ray crystallography and tomography, indicated that obinutuzumab binds CD20 in a 'closed' mode and rituximab in an 'open' mode which allows each mAb to associate with a different set of protein complexes (98) such as the BCR. Another explanation is that rituximab binds CD20 mainly in cis (within the CD20 tetramer), whereas obinutuzumab binds in trans - between CD20 tetramers (97). This permits rituximab to cross-link CD20 more effectively, forming CD20 clusters and aggregated Fc regions capable of associating with FcgRllb thus promoting internalisation of the mAbCD20 antigen complex (74), irrespective of the FcgRllb activation (99), a process not seen with type II mAbs. In addition to being a type II mAb, obinutuzumab is also glyco-engineered, with reduced fucosylation of its Fc portion - providing higher affinity binding to both low and high affinity variants of the FcgRIIla (CD16a) (100) and FcgRIIlb (CD16b) (101) and therefore improve the effectiveness of NK-mediated ADCC (102). The distinctions between the type I and type II anti-CD20 mAbs at inducing effector mechanisms for B cell depletion are detailed graphically in Figure 3.

It is important to consider whether the inherent immune dysregulation in SLE, impairs the anti CD20 effector mechanisms. With regards to complement, Kennedy and colleagues found that after rituximab infusion to patients with CLL, complement was rapidly consumed (103) whereas replacement of complement with fresh frozen plasma was shown to improve the efficiency of rituximab in in vitro assays on human CLL samples (104). However latter studies, in FL, concluded that the role of complement does not appear to be as crucial as previously suggested for B-cell depletion (105), and moreover the expression of CD20 has a greater influence on CDC (106). Thus, the role of CDC remains unclear in B cell malignancies.

Complement defects and deficiencies can result in an SLE-like condition (107)(108), so it seems logical to explore whether this influences the efficiency of anti-CD20 therapy. However, patients with lupus who are hypocomplementaemic and have high anti-dsDNA levels respond well to rituximab treatment (49). Furthermore, obinutuzumab achieved superior B cell depletion compared to rituximab in in vitro whole blood assays in SLE patient samples despite less potent activation of CDC (109). Therefore, based upon the fact that FcyR-mediated effector mechanisms and/or DCD are obinutuzumab's main mechanisms of action, complement may not be an important effector mechanism in SLE.

Both $A D C C$ and $A D C P$, which are mediated via FcgR, have a significant impact on B-cell depletion by anti-CD20 mAbs in malignant and autoimmune disease. In FL (110), ITP (111), RA (112) and SLE (41), the high affinity FcgRIlla $158 \mathrm{~V}$ polymorphism is predictive of a superior response to rituximab. This finding highlights the importance of anti-CD20mAb evoked ADCC and ADCP for B cell depletion. Healthy individuals who are homozygous for the lower affinity $158 \mathrm{~F} \mathrm{FcgRIlla} \mathrm{polymorphism} \mathrm{respond}$ better to obinutuzumab than rituximab with regards to ADCC assays of their effector cells. Therefore, 
in patients with SLE who have this low affinity allele, obinutuzumab with its afucosylated Fc portion and lower tendency to internalise may enable more potent B-cell depletion.

ADCP seems to be an important mechanism of B-cell depletion mediated by Kupffer cells, macrophages, monocytes and potentially neutrophils. Neutrophils are the predominant leukocyte in peripheral blood and they have been shown to phagocytose anti-CD20 opsonised B cells (113)(101). Activation of neutrophils can be demonstrated by up-regulation of the cell surface marker CD11b and down-regulation of the adhesion molecule CD62L. Obinutuzumab evokes increased activation of neutrophils compared to rituximab from whole blood samples of patients with SLE as assessed by an increase in the mean fluorescence intensity (MFI) of CD11b and decrease in the MFI of CD62L (109). Glycoengineered rituximab and obinutuzumab have demonstrated increased neutrophil-mediated phagocytosis of B cells coated with anti-CD20 mAb in whole blood assays, in comparison to standard non-glycoengineered rituximab (101). Macrophages are considered to be the crucial effector cells of B-cell depletion for malignant conditions (114). Due to lack of evidence, it is not known whether macrophage function as effector cells in patients with SLE treated with anti-CD20 mAbs.

In vitro experimental evidence alongside findings from mouse models suggests that excess immunoglobulins may dampen the effect of rituximab to a greater degree than obinutuzumab, likely through inhibition of Fc:FcyR dependent effector mechanisms (106). Patients with SLE often have hypergammaglobulinaemia, in this context, obinutuzumab bearing an afucosylated Fc would be expected to bind FcyRllla on effector cells with greater affinity than fucosylated anti-CD20mAbs such as rituximab.

With regards to $D C D$, data in autoimmune conditions in humans is limited, so our understanding is largely confined to studies in malignant cell lines. Rituximab mediates DCD via caspase-dependent apoptotic cell death (115), and obinutuzumab induces DCD through homotypic adhesion and nonapoptotic lysosomal cell death, which does not require further crosslinking (95)(116). Therefore, in Bcell subpopulations, which show differential expression of anti-apoptotic proteins, DCD induced by type II mAbs may not be affected (117). Elevated BAFF levels in SLE may result in poor response to rituximab through BAFF-mediated anti-apoptotic effects (118). The UCL group has demonstrated the greater potency of obinutuzumab compared to rituximab at depleting B cells in whole blood samples from patients with SLE. This was shown to be predominantly through FcyR-dependent and independent effector mechanisms despite inefficient CDC (109). Thus, obinutuzumab appears to induce superior B-cell depletion to rituximab in SLE patient samples.

\subsection{Clinical and practical considerations of anti-CD20mAbs}

\subsection{Potential combinations of these agents with other immunosuppressants}

The treatment of SLE often involves combination therapy. Initially this would be the conventional synthetic immunomodulators and immunosuppressive drugs as outlined above (section 2.1), and when disease activity is not controlled, a biologic agent for example Rituximab or Belimumab would be employed, usually in addition. Our previous published research has found that there was an association with sequential therapy of rituximab and MMF and an increased risk of lgM hypogammaglobulinemia. This was predicted by lower baseline IgM levels, but reassuringly was not associated with increased rates of infection (119). The LUNAR trial elegantly demonstrated that the combination of rituximab with MMF and corticosteroids did not result in any new safety concerns. In contrast, ocrelizumab (section 2.6.3) was associated with more serious infections in the subgroup treated with MMF (53), in its phase III trial in lupus nephritis.

In the EXPLORER trial, patients were receiving MMF, azathioprine or methotrexate and randomised to placebo or rituximab, and this combination of immunosuppression and $B$ cell depletion therapy also confirmed similar safety and tolerability (46). Both LUNAR (48) and EXPLORER trials demonstrated higher rates of neutropenia in the rituximab treated groups, however this did not result in an increased rate of infection. Contrary to expectation, serious infections were more prevalent in the placebo treated group compared to rituximab treated in both trials.

Both British (120), and French (121) registry data with at least 24 and 18 month follow up periods respectively, identified that the highest risk of serious infection was within the first 3 months of rituximab treatment, with a serious infection rate in $10 \%$ of patients. 
BEAT-Lupus is an ongoing clinical trial testing the combination of Rituximab and Belimumab in SLE, and we await the results of this to inform future treatment strategies in SLE (122). Initial results of the Phase 2 CALIBRATE study, testing the addition of Belimumab maintenance therapy following rituximab, cyclophosphamide and corticosteroid induction therapy, demonstrated no difference in the rate of renal response in patients with lupus nephritis at week 48 , but reassuringly there was no associated hypogammaglobulinaemia or increased rate of serious infections (123).

Patients with ANCA vasculitis experienced higher rates of post Rituximab infections after Rituximab compared to lupus. Long term outcome data published in ANCA-associated vasculitis of combined rituximab, cyclophosphamide and subsequent maintenance azathioprine or MMF demonstrated $30 \%$ of patients developing a grade III infection over a median 56 month follow up period, and 4 out of 66 patients had persistent hypogammaglobulinaemia and two patients required replacement intravenous immunoglobulin (124).

\subsubsection{Immunological adverse effects or autoimmune phenomena related to anti-CD20 mAbs}

The incidence of reported psoriasis following rituximab therapy is limited to case reports (125).

There are 9 reported cases of colitis developed following rituximab therapy for various indications, and this is postulated to be due to depletion of CD20+ B cells in the intestinal mucosa and high infiltration of T cells following administration of Rituximab (126). The RCT of using rituximab to treat moderately active ulcerative colitis resistant to steroids, however, showed that it was well tolerated, but had no significant effect on inducing remission (127). However, the long-term BSR registry has identified no increased risk of ulcerative colitis in patients with rheumatoid arthritis treated with Rituximab (128).

\subsubsection{Protocols for refractory lupus employing anti-CD20 therapies}

In England, Rituximab will only be funded for use in SLE where there is active disease (defined as at least one BILAG A score and/or 2B scores, or a SLEDAI-2K score $>6$ ) and failure to respond or intolerance to, two or more standard immunosuppressive therapies (one of which must be either MMF or cyclophosphamide), in combination with corticosteroids (129).

NHS England Commissioning Policy and the British Society of Rheumatology Guidelines advise the use of Rituximab at $2 \times 1000 \mathrm{mg}$ on day 0 and day 14 of an infusion cycle. This can be repeated at 6 months if there is evidence of disease recurrence and $B$ cell repopulation. This regimen is also recommended in the 2017 British Society of Rheumatology guidelines on the management of SLE (2). European and American rheumatology guidelines on the management of lupus nephritis recommend anti-CD20 therapy with Rituximab when MMF or cyclophosphamide has failed (130) (131).

\subsubsection{Organ involvement most positively affected by anti-CD20 mAbs}

Although the two main RCTs of Rituximab in SLE did not report the specific haematological outcomes, data from previous open label studies reports that Rituximab is effective for the treatment of severe haematological manifestations in SLE (132), in particular autoimmune thrombocytopenia and haemolytic anaemia.

Active proliferative lupus nephritis (class III and IV) has been shown to respond to Rituximab, which enabled a reduction in maintenance steroid dose (133). A cohort study of patients with refractory neuropsychiatric lupus has shown rapid improvement in both clinical and laboratory features of disease (134).

Patients with severe lupus often have renal, haematological and neurological involvement and most physicians would consider Rituximab in cases refractory to standard therapy, or if other treatments are contraindicated.

French registry data identified an improvement in articular, cutaneous, renal, and haematologic domains in $72 \%, 70 \%, 74 \%$, and $88 \%$ of patients, respectively, however subtypes of organ involvement were not reported (121).

With regards to cutaneous involvement, the subtypes acute and subacute show superior response rates following rituximab treatment compared to chronic cutaneous lupus erythematosus (135). This report of 17 patients treated with rituximab for cutaneous manifestations demonstrated that $B$ cell 
depletion was beneficial in particular in patients with acute, subacute or non-specific cutaneous lupus erythematosus, with over $66 \%$ in partial or complete remission, compared to only $37 \%$ in patients with chronic cutaneous disease, six months following treatment.

\subsubsection{Limitations for use of anti-CD20 mAbs}

Rituximab is contraindicated in those with previous hypersensitivity, active severe infection and severe heart failure (136).

Renal failure does not pose a risk to the use of Rituximab as it is a monoclonal antibody and clearance is unaffected by glomerular filtration. Prior to commencing Rituximab, immunoglobulin levels should be routinely monitored (137), as guidelines suggest low immunoglobulin $\mathrm{G}(\mathrm{lgG})<6 \mathrm{~g} / \mathrm{L}$ can increase the risk of infections (138).

The EXPLORER trial reported higher rates of neutropenia (8\% in the Rituximab treated group, compared to $3 \%$ in the placebo group) and herpes virus infections (15\% in Rituximab treated group, versus $8 \%$ in the placebo treated group) (46). BILAG registry data suggests that infections are most prevalent three months post treatment with rituximab in patients with SLE, and this may in part be explained by the higher corticosteroid dose at this time period, as well as possible hypogammaglobulinaemia and the period of maximal B cell depletion (120). This risk of infection post Rituximab, explains why the influenza and pneumococcal vaccinations are advised to be given at least two weeks prior to commencing such therapy. There have been reports of progressive multifocal leukoencephalopathy (PML) after rituximab treatment in patients with SLE as well as RA (139), however these are vanishingly rare and to our knowledge, none in the United Kingdom (140). We do however counsel patients about the risk of this when explaining the risks of anti CD20 mAb therapy.

Measuring circulating CD19+ B cells at baseline, can be helpful in predicting B-cell depletion time, which is faster with higher CD19+ B cell counts ((141). However, repeat rituximab treatment is given often to treat and prevent disease relapse regardless of the peripheral $\mathrm{B}$ cell count. A retrospective study showed that in autoimmune diseases as a whole, repeated rituximab infusions itself were not associated with an increased incidence of hypogammaglobulinaemia, whereas previous steroid and cyclophosphamide therapy were (140). Severe infections were not directly associated with immunoglobulin levels and only a small proportion of patients developed severe lgG hypogammaglobulinaemia requiring intravenous immunoglobulin treatment. Low IgM levels do not tend to play a part in increasing the risk of infection post rituximab.

\subsection{Future Perspectives}

Rituximab is the most widely used agent for B-cell depletion therapy in patients with SLE who have active disease that do not respond to conventional immunosuppression. Data from uncontrolled studies supports its continued use in this context. The use of Rituximab in mild to moderate disease is, however, not recommended. We now have the benefit of Belimumab, which is licensed for nonrenal, non-CNS lupus. Post marketing studies of Belimumab as well as registry data will provide further insights into real-life utility and its long-term safety profile. Abstract publication of BLISS-LN, a phase III trial of belimumab in patients with active LN demonstrated an $11 \%$ increased renal response rate when administering belimumab in addition to standard therapy compared to standard therapy alone (142). We await further studies of anti-BLyS treatment in African-American patients (143) and how other factors such as background therapy affect its outcomes.

The phase II NOBILITY study of obinutuzumab in proliferative lupus nephritis demonstrated superiority with regards to increased complete and partial renal responses when compared to placebo (plus standard of care, MMF and glucocorticoids) (144). We anticipate the results of the phase III study, which is currently underway (145). Head-to-head clinical trials with rituximab will provide a greater understanding of the biological and clinical differences between the types of anti-CD20 mAbs, but are not yet in the pipeline.

As well as the heterogeneity of clinical manifestations between individuals with lupus, there is a predictable underlying heterogeneity of B cell pathology, which is likely to determine response to different biologic therapies. Therefore, future treatment strategies towards 'personalised medicine' 
may be applied in this setting to allow targeting of specific pathways or B cell subsets according to the individual's immune dysregulation.

What are the prospects for using sequential biologics? There are current trends for combination or sequential therapy for example with the BEAT Lupus trial currently recruiting as a phase II randomised, double blind, placebo controlled trial to investigate the safety and efficacy of Belimumab following B-cell depletion therapy with Rituximab. This is following the identification of a rise in BAFF and anti-dsDNA antibodies in patients with a lupus flare following previous rituximab treatment, and it appears that BAFF perpetuates autoreactive B cells. The primary outcome measure is anti-dsDNA antibody levels at 52 weeks (122). Other pathways in the pathogenesis of lupus are also being targeted, particularly important for patients with elevated type I interferons, produced by dendritic cells which leads to tissue damage and disease exacerbation (146). Recognising this, sequential therapy with interferon antagonists such as anifrolumab may overcome resistance to rituximab.

A subgroup of patients who do not respond to rituximab may have elevated anti-dsDNA antibodies probably secreted by long lived plasma cells. Therefore, treatments designed for plasma cell dyscrasias such as proteasome inhibitors for example Bortezomib may be beneficial in this group of SLE patients. A trial of 12 patients treated with iv bortezomib and dexamethasone for active SLE demonstrated reduction in disease activity and $60 \%$ improvement in anti-dsDNA antibody levels, however the unwanted side effect profile resulted in over half of patients discontinuing treatments (147).

As with biologic therapy in rheumatoid arthritis progressing from intravenous anti-TNF infliximab, to then home treatment with subcutaneous etanercept or adalimumab, and now the use of oral treatment with JAK inhibitors, the mode of delivery of treatments in SLE is being increasingly considered. The young population of working age need convenient treatments, which are selfdeliverable and so more subcutaneous and oral options are being generated. As discussed earlier, multiple pro-inflammatory cytokines are responsible for the tissue damage in SLE, and therefore inhibitors of the JAK family of cytoplasmic protein tyrosine kinases have been studied in lupus in a recent phase II RCT (148). They demonstrated that the small molecule selective and reversible inhibitor of JAK1 and JAK2, Baricitinib, at the higher dose of $4 \mathrm{mg}$ significantly improved rash and arthritis at 24 week follow up, by $67 \%$ in 104 patients, compared to placebo. This provides rationale for a phase III clinical trial, which will need to be optimised through careful patient selection considering a positive gene signature or those with higher pre-treatment disease activity scores.

Another treatment strategy, which could be adopted from rheumatoid arthritis is 'treating to target'. If a robust biomarker of impending lupus flare was identified such as a certain B cell subpopulation via high sensitivity flow cytometry, this could be incorporated into a treat to target composite score to guide physicians in providing timely and effective treatment.

\section{Conclusions}

The treatment of lupus has been revolutionised by the use of anti-CD20 therapies in patients who are refractory to conventional therapy. Long term outcome data of Rituximab has been very encouraging in uncontrolled studies, yet not confirmed in controlled trials due to a number of reasons including trial design, patient cohorts, background treatment and the duration of follow up. The response to Rituximab is variable and reasons to explain this range from the ability of rituximab to recruit immune effector cells to deplete B cells, HACAs and internalisation of Rituximab impairing its efficiency to engage with the effector cells. In order to understand and optimise the efficiency of B cell depletion therapy in lupus, type II monoclonal antibody against CD20, Obinutuzumab, is undergoing randomised controlled trials. The mechanistic advantage of Obinutuzumab besides its glycoengineered Fc portion, which allows superior engagement with Fcgamma receptor bearing effector cells, it is less likely to be internalised compared to rituximab and is therefore predicted to induce more efficient B-cell depletion. Combination biologic therapy may be the future of refractory lupus treatment; we anticipate the outcomes from current clinical trials to inform us.

\section{Tables, Figures \& Figure captions are on separate uploaded files}




\section{Acknowledgments}

Dr Reddy's work on this review is supported by the Doris Hillier Grant 2018.

\section{Conflict of Interest}

The authors have no conflicts of interest to report.

\section{References}

1. Rahman A, Isenberg DA. Systemic Lupus Erythematosus. 2008;929-39.

2. Gordon C, Amissah-Arthur MB, Gayed M, Brown S, Bruce IN, D'Cruz D, et al. The British Society for Rheumatology guideline for the management of systemic lupus erythematosus in adults: reply. Rheumatology (Oxford). 2018;57(8):1502-3.

3. Alarcón GS, McGwin G, Bertoli AM, Fessler BJ, Calvo-Alén J, Bastian HM, et al. Effect of hydroxychloroquine on the survival of patients with systemic lupus erythematosus: Data from LUMINA, a multiethnic US cohort (LUMINA L). Ann Rheum Dis. 2007;

4. Pons-Estel GJ, Alarcón GS, McGwin Jr G, Danila MI, Zhang J, Bastian HM, et al. Protective effect of hydroxychloroquine on renal damage in patients with lupus nephritis: LXV, data from a multiethnic US cohort. Arthritis Rheum [Internet]. 2009 Jun 15;61(6):830-9. Available from: https://www.ncbi.nlm.nih.gov/pubmed/19479701

5. Allison AC, Eugui EM. Mycophenolate mofetil and its mechanisms of action. Immunopharmacology. 2000.

6. Ginzler EM, Wofsy D, Isenberg D, Gordon C, Lisk L, Dooley MA. Nonrenal disease activity following mycophenolate mofetil or intravenous cyclophosphamide as induction treatment for lupus nephritis: Findings in a multicenter, prospective, randomized, open-label, parallel-group clinical trial. Arthritis Rheum. 2010;

7. Dooley MA, Jayne D, Ginzler EM, Isenberg D, Olsen NJ, Wofsy D, et al. Mycophenolate versus Azathioprine as Maintenance Therapy for Lupus Nephritis. N Engl J Med. 2011;

8. Foley GE, Friedman OM, Drolet BP. Studies on the Mechanism of Action of Cytoxan Evidence of Activation \&lt;em\&gt;in Vivo\&lt;/em\&gt; and \&lt;em\&gt;in Vitro\&lt;/em\&gt; Cancer Res [Internet]. 1961 Jan 1;21(1):57 LP - 63. Available from: http://cancerres.aacrjournals.org/content/21/1/57.abstract

9. Hannah J, Casian A, D'Cruz D. Tacrolimus use in lupus nephritis: A systematic review and meta-analysis. Autoimmun Rev [Internet]. 2016;15(1):93-101. Available from: http://dx.doi.org/10.1016/j.autrev.2015.09.006

10. Teng YO, Parikh S V, Saxena A, Solomons N, Huizinga RB. O11 AURORA phase 3 study demonstrates voclosporin statistical superiority over standard of care in lupus nephritis (LN). In 2020. 
11. Scott D (Kings CL, Wolfe F, Huizinga T. Rheumatoid arthritis. Lancet. 2010;376(9746):1094108.

12. Lipsky PE. Systemic lupus erythematosus: An autoimmune disease of B cell hyperactivity. Nat Immunol. 2001;

13. Olsen NJ, Karp DR. Autoantibodies and SLE - The threshold for disease. Nature Reviews Rheumatology. 2014.

14. Koffler D, Schur PH, Kunkel HG, Koffler BD. IMMUNOLOGICAL STUDIES CONCERNING THE NEPHRITIS OF SYSTEMIC LUPUS ERYTHEMATOSUS *. J Exp Med. 1967;

15. Isenberg DA, Shoenfeld Y, Walport M, Mackworth-Young C, Dudeney C, Todd-Pokropek A, et al. Detection of cross-reactive anti-DNA antibody idiotypes in the serum of systemic lupus erythematosus patients and of their relatives. Arthritis Rheum. 1985;

16. Isenberg DA, Manson JJ, Ehrenstein MR, Rahman A. Fifty years of anti-ds DNA antibodies: Are we approaching journey's end? Rheumatology. 2007.

17. Fernando MMA, Isenberg DA. How to monitor SLE in routine clinical practice. Annals of the Rheumatic Diseases. 2005.

18. Giltiay N V., Chappell CP, Clark EA. B-cell selection and the development of autoantibodies. Arthritis Research and Therapy. 2012.

19. Yurasov S, Wardemann H, Hammersen J, Tsuiji M, Meffre E, Pascual V, et al. Defective B cell tolerance checkpoints in systemic lupus erythematosus. J Exp Med. 2005;

20. Cambridge G, Moura RA, Santos T, Khawaja AA, Polido-Pereira J, Canhão H, et al. Expression of the inherently autoreactive idiotope $9 \mathrm{G} 4$ on autoantibodies to citrullinated peptides and on rheumatoid factors in patients with early and established rheumatoid arthritis. PLoS One. 2014;

21. Cappione A, Anolik JH, Pugh-Bernard A, Barnard J, Dutcher P, Silverman G, et al. Germinal center exclusion of autoreactive $B$ cells is defective in human systemic lupus erythematosus. $J$ Clin Invest. 2005;

22. Jacobi AM, Reiter K, Mackay M, Aranow C, Hiepe F, Radbruch A, et al. Activated memory B cell subsets correlate with disease activity in systemic lupus erythematosus: Delineation by expression of CD27, IgD, and CD95. Arthritis Rheum. 2008;

23. Muñoz LE, Lauber K, Schiller M, Manfredi AA, Herrmann M. The role of defective clearance of apoptotic cells in systemic autoimmunity. Nat Rev Rheumatol [Internet]. 2010 May 1;6:280. Available from: https://doi.org/10.1038/nrrheum.2010.46

24. Batten M, Groom J, Cachero TG, Qian F, Schneider P, Tschopp J, et al. BAFF mediates survival of peripheral immature B lymphocytes. J Exp Med. 2000;

25. Jacobi AM, Odendahl M, Reiter K, Bruns A, Burmester GR, Radbruch A, et al. Correlation between circulating CD27highplasma cells and disease activity in patients with systemic lupus erythematosus. Arthritis Rheum. 2003;48(5):1332-42. 
26. Edwards JCW, Cambridge G. B-cell targeting in rheumatoid arthritis and other autoimmune diseases. Nature Reviews Immunology. 2006.

27. NICE. Belimumab for treating active autoantibody-positive systemic lupus erythematosus (TA397). 2016;(June 2016). Available from: nice.org.uk/guidance/ta397\%0A

28. Navarra S V., Guzmán RM, Gallacher AE, Hall S, Levy RA, Jimenez RE, et al. Efficacy and safety of belimumab in patients with active systemic lupus erythematosus: A randomised, placebo-controlled, phase 3 trial. Lancet. 2011;

29. Furie R, Petri M, Zamani O, Cervera R, Wallace DJ, Tegzová D, et al. A phase III, randomized, placebo-controlled study of belimumab, a monoclonal antibody that inhibits $B$ lymphocyte stimulator, in patients with systemic lupus erythematosus. Arthritis Rheum. 2011;

30. Salazar-Camarena DC, Ortiz-Lazareno PC, Cruz A, Oregon-Romero E, Machado-Contreras JR, Muñoz-Valle JF, et al. Association of BAFF, APRIL serum levels, BAFF-R, TACl and $B C M A$ expression on peripheral B-cell subsets with clinical manifestations in systemic lupus erythematosus. Lupus. 2016;

31. Wu D, Li J, Xu D, Wang W, Li L, Fang J, et al. A Human Recombinant Fusion Protein Targeting B Lymphocyte Stimulator ( BlyS ) and a Proliferation-Inducing Ligand ( APRIL ), Telitacicept ( RC18), in Systemic Lupus Erythematosus ( SLE ): Results of a Phase 2b Study. Arthritis Rheumatol. 2019;71 (suppl.

32. Banchereau J, Pascual V. Type I Interferon in Systemic Lupus Erythematosus and Other Autoimmune Diseases. Immunity. 2006.

33. Khamashta M, Merrill JT, Werth VP, Furie R, Kalunian K, Illei GG, et al. Sifalimumab, an antiinterferon- $\alpha$ monoclonal antibody, in moderate to severe systemic lupus erythematosus: $A$ randomised, double-blind, placebo-controlled study. Ann Rheum Dis. 2016;

34. Furie R, Khamashta M, Merrill JT, Werth VP, Kalunian K, Brohawn P, et al. Anifrolumab, an Anti-Interferon- $\alpha$ Receptor Monoclonal Antibody, in Moderate-to-Severe Systemic Lupus Erythematosus. Arthritis Rheumatol. 2017;

35. Morand EF, Furie R, Tanaka Y, Bruce IN, Askanase AD, Richez C, et al. Trial of Anifrolumab in Active Systemic Lupus Erythematosus. N Engl J Med [Internet]. 2019 Dec 18;382(3):21121. Available from: https://doi.org/10.1056/NEJMoa1912196

36. Edwards JCW, Cambridge G. Sustained improvement in rheumatoid arthritis following a protocol designed to deplete B lymphocytes. Rheumatology. 2001;

37. Edwards JCW, Szczepański L, Szechiński J, Filipowicz-Sosnowska A, Emery P, Close DR, et al. Efficacy of B-Cell-Targeted Therapy with Rituximab in Patients with Rheumatoid Arthritis. N Engl J Med. 2004;

38. Leandro MJ, Edwards JC, Cambridge G, Ehrenstein MR, Isenberg DA. An open study of B lymphocyte depletion in systemic lupus erythematosus. Arthritis Rheum. 2002;

39. Hay EM, Bacon PA, Gordon C, Isenberg DA, Maddison P, Snaith ML, et al. The bilag index: a reliable and valid instrument for measuring clinical disease activity in systemic lupus erythematosus. QJM. 1993; 
40. Turner-Stokes T, Lu TY, Ehrenstein MR, Giles I, Rahman A, Isenberg DA. The efficacy of repeated treatment with $\mathrm{B}$-cell depletion therapy in systemic lupus erythematosus: an evaluation. Rheumatology (Oxford). 2011;

41. Anolik JH, Campbell D, Felgar RE, Young F, Sanz I, Rosenblatt J, et al. The relationship of FcyRIlla genotype to degree of $B$ cell depletion by rituximab in the treatment of systemic lupus erythematosus. Arthritis Rheum. 2003;

42. Looney RJ, Anolik JH, Campbell D, Felgar RE, Young F, Arend LJ, et al. B cell depletion as a novel treatment for systemic lupus erythematosus: A phase I/II dose-escalation trial of rituximab. Arthritis Rheum. 2004;

43. Albert D, Dunham J, Khan S, Stansberry J, Kolasinski S, Tsai D, et al. Variability in the biological response to anti-CD20 B cell depletion in systemic lupus erythaematosus. Ann Rheum Dis. 2008;

44. Ramos-Casals M, Soto MJ, Cuadrado MJ, Khamashta MA. Rituximab in systemic lupus erythematosus A systematic review of off-label use in 188 cases. Lupus. 2009.

45. Díaz-Lagares C, Croca S, Sangle S, Vital EM, Catapano F, Martínez-Berriotxoa A, et al. Efficacy of rituximab in 164 patients with biopsy-proven lupus nephritis: Pooled data from European cohorts. Autoimmunity Reviews. 2012.

46. Merrill JT, Neuwelt CM, Wallace DJ, Joseph C, Latinis KM, Oates JC, et al. Efficacy and Safety of Rituximab in Moderately-to-Severely Active Systemic Lupus Erythematosus: The Randomized, Double-Blind, Phase II/III Systemic Lupus Erythematosus Evaluation of Rituximab Trial. Arthritis Rheumatol. 2010;62(1):222-33.

47. Alarcón GS, Roseman JM, McGwin G, Uribe A, Bastian HM, Fessler BJ, et al. Systemic lupus erythematosus in three ethnic groups. XX. Damage as a predictor of further damage. Rheumatology. 2004;

48. Rovin BH, Furie R, Latinis K, Looney RJ, Fervenza FC, Sanchez-Guerrero J, et al. Efficacy and safety of rituximab in patients with active proliferative lupus nephritis: the Lupus Nephritis Assessment with Rituximab study. Arthritis Rheum. 2012;64(4):1215-26.

49. Reddy V, Jayne D, Close D, Isenberg D. B-cell depletion in SLE : clinical and trial experience with rituximab and ocrelizumab and implications for study design. 2013;15(Suppl 1):1-16.

50. Stone JH. Rituximab versus cyclophosphamide for ANCA-associated vasculitis. Journal fur Mineralstoffwechsel. 2010.

51. Vital EM, Dass S, Buch MH, Henshaw K, Pease CT, Martin MF, et al. B cell biomarkers of rituximab responses in systemic lupus erythematosus. Arthritis Rheum. 2011;

52. Dias SS, Rodriguez-garcia V, Nguyen H, Pericleous C, Isenberg D. Longer duration of B cell depletion is associated with better outcome. Rheumatol (United Kingdom). 2015;

53. Mysler EF, Spindler AJ, Guzman R, Bijl M, Jayne D, Furie RA, et al. Efficacy and safety of ocrelizumab in active proliferative lupus nephritis: Results from a randomized, double-blind, phase III study. Arthritis Rheum. 2013;65(9):2368-79. 
54. Syed YY. Ocrelizumab: A Review in Multiple Sclerosis. CNS Drugs. 2018.

55. Thornton CC, Ambrose N, loannou Y. Ofatumumab: A novel treatment for severe systemic lupus erythematosus. Rheumatology (United Kingdom). 2015.

56. Md Yusof MY, Shaw D, El-Sherbiny YM, Dunn E, Rawstron AC, Emery P, et al. Predicting and managing primary and secondary non-response to rituximab using B-cell biomarkers in systemic lupus erythematosus. Ann Rheum Dis. 2017;

57. Sandhu S, Mulligan SP. Ofatumumab and its role as immunotherapy in chronic lymphocytic leukemia. Haematologica. 2015.

58. Hauser SL, Bar-Or A, Cohen JA, Comi G, Correale J, Coyle PK, et al. Ofatumumab versus Teriflunomide in Multiple Sclerosis. N Engl J Med. 2020;

59. Berinstein NL, Grillo-Lopez AJ, White CA, Bence-Bruckler I, Maloney D, Czuczman M, et al. Association of serum Rituximab (IDEC-C2B8) concentration and anti-tumor response in the treatment of recurrent low-grade or follicular non-Hodgkin's lymphoma. Ann Oncol [Internet]. 1998 Sep 1;9(9):995-1001. Available from: http://dx.doi.org/10.1023/A:1008416911099

60. V Beum P, Kennedy A, Taylor R. Three new assays for rituximab based on its immunological activity or antigenic properties: Analyses of sera and plasmas of RTX-treated patients with chronic lymphocytic leukemia and other B cell lymphomas. Vol. 289, Journal of immunological methods. 2004. 97-109 p.

61. Tobinai K, Kobayashi $\mathrm{Y}$, Narabayashi M, Ogura M, Kagami $\mathrm{Y}$, Morishima $\mathrm{Y}$, et al. Feasibility and pharmacokinetic study of a chimeric anti-CD20 monoclonal antibody (IDEC-C2B8, rituximab) in relapsed B-cell lymphoma. Ann Oncol. 1998;

62. O'Brien SM, Kantarjian H, Thomas DA, Giles FJ, Freireich EJ, Cortes J, et al. Rituximab doseescalation trial in chronic lymphocytic leukemia. J Clin Oncol. 2001;

63. Igarashi T, Kobayashi Y, Ogura M, Kinoshita T, Ohtsu T, Sasaki Y, et al. Factors affecting toxicity, response and progression-free survival in replased patients with indolent B-cell lymphoma and mantle cell lymphoma treated with rituximab: A Japanese phase II study. Vol. 13, Annals of oncology : official journal of the European Society for Medical Oncology / ESMO. 2002. 928-943 p.

64. Vital EM, Rawstron AC, Dass S, Henshaw K, Madden J, Emery P, et al. Reduced-dose rituximab in rheumatoid arthritis: Efficacy depends on degree of $B$ cell depletion. Arthritis Rheum. 2011;

65. Vital EM, Dass S, Buch MH, Rawstron AC, Emery P, Kvien TK. An extra dose of rituximab improves clinical response in rheumatoid arthritis patients with initial incomplete $B$ cell depletion: A randomised controlled trial. Ann Rheum Dis. 2015;

66. Reddy V, Croca S, Gerona D, De La Torre I, Isenberg D, McDonald V, et al. Serum rituximab levels and efficiency of $b$ cell depletion: Differences between patients with rheumatoid arthritis and systemic lupus erythematosus. Rheumatology (United Kingdom). 2013.

67. Levy J, Barnett E V., MacDonald NS, Klinenberg JR. Altered immunoglobulin metabolism in systemic lupus erythematosus and rheumatoid arthritis. J Clin Invest. 1970; 
68. Reff M, Carner K, Chambers K, Chinn P, Leonard J, Raab R, et al. Depletion of B Cells In Vivo by a Chimeric Mouse Human Monoclonal Antibody to CD20. Blood. 1994;

69. Kamburova EG, Koenen HJPM, Borgman KJE, Ten Berge IJ, Joosten I, Hilbrands LB. A single dose of rituximab does not deplete $b$ cells in secondary lymphoid organs but alters phenotype and function. Am J Transplant. 2013;

70. Wallin EF, Jolly EC, Suchánek O, Bradley JA, Espéli M, Jayne DRW, et al. Human T-follicular helper and T-follicular regulatory cell maintenance is independent of germinal centers. Blood. 2014;

71. Almasri NM, Duque RE, Iturraspe J, Everett E, Braylan RC. Reduced expression of CD20 antigen as a characteristic marker for chronic lymphocytic leukemia. Am J Hematol. 1992;

72. Smith MR. Rituximab (monoclonal anti-CD20 antibody): Mechanisms of action and resistance. Oncogene. 2003;

73. Maloney DG, Liles TM, Czerwinski DK, Waldichuk C, Rosenberg J, Grillo-Lopez a, et al. Phase I clinical trial using escalating single-dose infusion of chimeric anti-CD20 monoclonal antibody (IDEC-C2B8) in patients with recurrent B-cell lymphoma. Blood. 1994;

74. Beers SA, French RR, Chan HTC, Lim SH, Jarrett TC, Vidal RM, et al. Antigenic modulation limits the efficacy of anti-CD20 antibodies: Implications for antibody selection. Blood. 2010;

75. Lim SH, Vaughan AT, Ashton-Key M, Williams EL, Dixon S V., Chan HTC, et al. Fc gamma receptor Illb on target $\mathrm{B}$ cells promotes rituximab internalization and reduces clinical efficacy. Blood. 2011;

76. Weng WK, Levy R. Genetic polymorphism of the inhibitory IgG Fc receptor FccRIlb is not associated with clinical outcome in patients with follicular lymphoma treated with rituximab. Leuk Lymphoma. 2009;

77. Siang Lee C, Ashton-Key M, Cogliatti S, Crowe S, Cragg M, Hsu Schmitz S-F, et al. Expression of inhibitory Fc receptor (FcyRIIB) is a marker of poor response to rituximab monotherapy in follicular lymphoma. Vol. 381, The Lancet. 2013. S63 p.

78. Taylor RP, Lindorfer MA. Fcy-receptor-mediated trogocytosis impacts mAb-based therapies: Historical precedence and recent developments. Blood. 2015;

79. Jones JD, Hamilton BJ, Rigby WFC. Rituximab mediates loss of CD19 on B cells in the absence of cell death. Arthritis Rheum. 2012;

80. Dahal LN, Huang C-Y, Stopforth RJ, Mead A, Chan K, Bowater JX, et al. Shaving Is an Epiphenomenon of Type I and II Anti-CD20-Mediated Phagocytosis, whereas Antigenic Modulation Limits Type I Monoclonal Antibody Efficacy. J Immunol. 2018;

81. Leandro MJ. B-cell subpopulations in humans and their differential susceptibility to depletion with anti-CD20 monoclonal antibodies. Vol. 15, Arthritis Research and Therapy. 2013.

82. Hultin LE, Hausner MA, Hultin PM, Giorgi J V. Cd20 (pan-B cell) antigen is expressed at a low level on a subpopulation of human T lymphocytes. Cytometry. 1993; 
83. Leandro MJ, Cambridge G, Ehrenstein MR, Edwards JCW. Reconstitution of peripheral blood $B$ cells after depletion with rituximab in patients with rheumatoid arthritis. Arthritis Rheum. 2006;

84. Stashenko P, Nadler LM, Hardy R, Schlossman SF. Characterization of a human B lymphocyte-specific antigen. J Immunol. 1980;

85. Liang Y, Buckley TR, Tu L, Langdon SD, Tedder TF. Structural organization of the human MS4A gene cluster on Chromosome 11q12. Immunogenetics. 2001;

86. Tedder TF, Engel P. CD20: a regulator of cell-cycle progression of B lymphocytes. Immunol Today. 1994;

87. Kuijpers TW, Bende RJ, Baars PA, Grummels A, Derks IAM, Dolman KM, et al. CD20 deficiency in humans results in impaired T cell-independent antibody responses. J Clin Invest. 2010;

88. Polyak MJ, Li H, Shariat N, Deans JP. CD20 homo-oligomers physically associate with the B cell antigen receptor: Dissociation upon receptor engagement and recruitment of phosphoproteins and calmodulin-binding proteins. J Biol Chem. 2008;

89. Walshe CA, Beers SA, French RR, Chan CHT, Johnson PW, Packham GK, et al. Induction of cytosolic calcium flux by $\mathrm{CD} 20$ is dependent upon $\mathrm{B}$ cell antigen receptor signaling. J Biol Chem. 2008;

90. Deans JP, Li H, Polyak MJ. CD20-mediated apoptosis: Signalling through lipid rafts. Immunology. 2002.

91. Tedder TF, Forsgren A, Boyd AW, Nadler LM, Schlossman SF. Antibodies reactive with the B1 molecule inhibit cell cycle progression but not activation of human B lymphocytes. Eur $\mathrm{J}$ Immunol. 1986;

92. Reddy V, Dahal LN, Cragg MS, Leandro M. Optimising B-cell depletion in autoimmune disease: is obinutuzumab the answer? Drug Discovery Today. 2016.

93. Roche H-L. A Study to Evaluate the Safety and Efficacy of Obinutuzumab Compared With Placebo in Participants With Lupus Nephritis (LN) NCT02550652. ClinicalTrials.gov [Internet]. 2015; Available from: https://www.clinicaltrials.gov/ct2/show/NCT02550652

94. Cragg MS, Morgan SM, Chan HTC, Morgan BP, Filatov A V., Johnson PWM, et al. Complement-mediated lysis by anti-CD20 mAb correlates with segregation into lipid rafts. Blood. 2003;

95. Beers SA, Chan CHT, James S, French RR, Attfield KE, Brennan CM, et al. Type II (tositumomab) anti-CD20 monoclonal antibody out performs type I (rituximab-like) reagents in B-cell depletion regardless of complement activation. Blood. 2008;

96. Tipton TRW, Roghanian A, Oldham RJ, Carter MJ, Cox KL, Mockridge Cl, et al. Antigenic modulation limits the effector cell mechanisms employed by type I anti-CD20 monoclonal antibodies. Blood. 2015;

97. Klein C, Lammens A, Schäfer W, Georges G, Schwaiger M, Mössner E, et al. Epitope 
interactions of monoclonal antibodies targeting CD20 and their relationship to functional properties. MAbs. 2013;

98. Niederfellner G, Lammens A, Mundigl O, Georges GJ, Schaefer W, Schwaiger M, et al. Epitope characterization and crystal structure of GA101 provide insights into the molecular basis for type I/II distinction of CD20 antibodies. Blood. 2011;

99. Vaughan AT, Iriyama C, Beers SA, Chan CHT, Lim SH, Williams EL, et al. Inhibitory FcyRIllb (CD32b) becomes activated by therapeutic $\mathrm{mAb}$ in both cis and trans and drives internalization according to antibody specificity. Blood. 2014;

100. Mössner E, Brünker P, Moser S, Püntener U, Schmidt C, Herter S, et al. Increasing the efficacy of CD20 antibody therapy through the engineering of a new type II anti-CD20 antibody with enhanced direct and immune effector cell - mediated B-cell cytotoxicity. Blood. 2010;

101. Golay J, Da Roit F, Bologna L, Ferrara C, Leusen JH, Rambaldi A, et al. Glycoengineered CD20 antibody obinutuzumab activates neutrophils and mediates phagocytosis through CD16B more efficiently than rituximab. Blood. 2013;

102. Umaña $P$, Jean-Mairet $J$, Moudry $R$, Amstutz $H$, Bailey JE. Engineered glycoforms of an antineuroblastoma IgG1 with optimized antibody-dependent cellular cytotoxic activity. Nat Biotechnol. 1999;

103. Kennedy AD, Beum P V., Solga MD, DiLillo DJ, Lindorfer MA, Hess CE, et al. Rituximab Infusion Promotes Rapid Complement Depletion and Acute CD20 Loss in Chronic Lymphocytic Leukemia. J Immunol. 2004;

104. Klepfish A, Schattner A, Ghoti H, Rachmilewitz EA. Addition of fresh frozen plasma as a source of complement to rituximab in advanced chronic lymphocytic leukaemia. Lancet Oncol. 2007;

105. Weng WK, Levy R. Two immunoglobulin $\mathrm{G}$ fragment $\mathrm{C}$ receptor polymorphisms independently predict response to rituximab in patients with follicular lymphoma. J Clin Oncol. 2003;

106. Bologna L, Gotti E, Manganini M, Rambaldi A, Intermesoli T, Introna M, et al. Mechanism of Action of Type II, Glycoengineered, Anti-CD20 Monoclonal Antibody GA101 in B-Chronic Lymphocytic Leukemia Whole Blood Assays in Comparison with Rituximab and Alemtuzumab. J Immunol. 2011;

107. Walport MJ, Davies KA, Botto M. C1q Deficiencies and C1q in Autoimmunity C1q and Systemic Lupus Erythematosus. Immunobiology. 1998;199(2):265-85.

108. Walport MJ. Complement and systemic lupus erythematosus. Arthritis Res. 2002;4(Supplement 3):279-93.

109. Reddy V, Klein C, Isenberg DA, Glennie MJ, Cambridge G, Cragg MS, et al. Obinutuzumab induces superior B-cell cytotoxicity to rituximab in rheumatoid arthritis and systemic lupus erythematosus patient samples. Rheumatol (United Kingdom). 2017;56(7):1227-37.

110. Cartron G, Dacheux L, Salles G, Solal-Celigny P, Bardos $P$, Colombat $P$, et al. Therapeutic activity of humanized anti-CD20 monoclonal antibody and polymorphism in IgG Fc receptor Fcyrllla gene. Blood. 2002; 
111. Cooper N, Stasi R, Cunningham-Rundles S, Cesarman E, Mcfarland JG, Bussel JB. Plateletassociated antibodies, cellular immunity and FCGR3a genotype influence the response to rituximab in immune thrombocytopenia. Br J Haematol. 2012;

112. Kastbom A, Cöster L, Ärlestig L, Chatzidionysiou A, Van Vollenhoven RF, Padyukov L, et al. Influence of FCGR3A genotype on the therapeutic response to rituximab in rheumatoid arthritis: An observational cohort study. BMJ Open. 2012;

113. Shibata-Koyama M, lida S, Misaka H, Mori K, Yano K, Shitara K, et al. Nonfucosylated rituximab potentiates human neutrophil phagocytosis through its high binding for FcyRIllb and MHC class II expression on the phagocytotic neutrophils. Exp Hematol. 2009;

114. Canioni D, Salles G, Mounier N, Brousse N, Keuppens M, Morchhauser F, et al. High numbers of tumor-associated macrophages have an adverse prognostic value that can be circumvented by rituximab in patients with follicular lymphoma enrolled onto the GELA-GOELAMS FL-2000 trial. J Clin Oncol. 2008;

115. Szodoray P, Alex P, Dandapani V, Nakken B, Pesina J, Kim X, et al. Apoptotic effect of rituximab on peripheral blood B cells in rheumatoid arthritis. Scand J Immunol. 2004;

116. Ivanov A, Beers SA, Walshe CA, Honeychurch J, Alduaij W, Cox KL, et al. Monoclonal antibodies directed to CD20 and HLA-DR can elicit homotypic adhesion followed by lysosomemediated cell death in human lymphoma and leukemia cells. J Clin Invest. 2009;

117. Shen Y, Iqbal J, Xiao L, Lynch RC, Rosenwald A, Staudt LM, et al. Distinct gene expression profiles in different B-cell compartments in human peripheral lymphoid organs. BMC Immunol. 2004;

118. Craxton A, Draves KE, Gruppi A, Clark EA. BAFF regulates B cell survival by downregulating the $\mathrm{BH} 3$-only family member Bim via the ERK pathway. J Exp Med. 2005;

119. Reddy V, Martinez L, Isenberg DA, Leandro MJ, Cambridge G. Pragmatic Treatment of Patients With Systemic Lupus Erythematosus With Rituximab: Long-Term Effects on Serum Immunoglobulins. Arthritis Care Res. 2017;

120. McCarthy EM, Sutton E, Nesbit S, White J, Parker B, Jayne D, et al. Short-term efficacy and safety of rituximab therapy in refractory systemic lupus erythematosus: Results from the british isles lupus assessment group biologics register. Rheumatol (United Kingdom). 2018;57(3):470-9.

121. Terrier B, Amoura Z, Ravaud P, Hachulla E, Jouenne R, Combe B, et al. Safety and efficacy of rituximab in systemic lupus erythematosus: Results from 136 patients from the French autoimmunity and rituximab registry. Arthritis Rheum. 2010;

122. Ehrenstein $\mathrm{M}(\mathrm{UCL})$. Belimumab after $\mathrm{B}$ Cell depletion therapy as a new treatment for patients with systemic lupus erythematosus (SLE) [Internet]. Arthritis Research UK. 2016 [cited 2018 Dec 15]. Available from: http://www.isrctn.com/ISRCTN47873003

123. Aranow C, Dall'Era M, Byron M, Ding L, Smilek D, Diamond B, et al. FRI0305 Phase 2 trial of induction therapy with anti-cd20 (RITUXIMAB) followed by maintenance therapy with anti-baff (BELIMUMAB) in patients with active lupus nephritis. Ann Rheum Dis [Internet]. 2018;77(Suppl 2):690 LP - 690. Available from: http://ard.bmj.com/content/77/Suppl_2/690.1.abstract 
124. McAdoo SP, Medjeral-Thomas N, Gopaluni S, Tanna A, Mansfield N, Galliford J, et al. Longterm follow-up of a combined rituximab and cyclophosphamide regimen in renal anti-neutrophil cytoplasm antibody-associated vasculitis. Nephrol Dial Transplant [Internet]. 2018;1-11. Available from: https://academic.oup.com/ndt/advance-article/doi/10.1093/ndt/gfx378/4859696

125. Dass S, Vital EM, Emery P. Development of psoriasis after B cell depletion with rituximab. Arthritis Rheum. 2007;

126. Shahmohammadi S, Sahraian MA, Shahmohammadi A, Doosti R, Zare-Mirzaie A, Naser Moghadasi A. A presentation of ulcerative colitis after rituximab therapy in a patient with multiple sclerosis and literature review. Mult Scler Relat Disord [Internet].

2018;22(February):22-6. Available from: https://doi.org/10.1016/j.msard.2018.02.030

127. Leiper K, Martin K, Ellis A, Subramanian S, Watson AJ, Christmas SE, et al. Randomised placebo-controlled trial of rituximab (anti-CD20) in active ulcerative colitis. Gut. 2011;

128. Oldroyd AGS, Symmons DPM, Sergeant JC, Kearsley-Fleet L, Watson K, Lunt M, et al. Longterm persistence with rituximab in patients with rheumatoid arthritis. Rheumatol (United Kingdom). 2018;

129. NHS England. Interim Clinical Commissioning Policy Statement: Rituximab for the treatment of Systemic Lupus Erythematosus in adults September 2013 Reference: NHS ENGLAND A13/PS/a. 2013;(September):1-10. Available from: https://www.england.nhs.uk/wpcontent/uploads/2013/09/a13-psa.pdf

130. Bertsias GK, Tektonidou M, Amoura Z, Aringer M, Bajema I, Berden JHM, et al. Joint European League Against Rheumatism and European Renal Association-European Dialysis and Transplant Association (EULAR/ERA-EDTA) recommendations for the management of adult and paediatric lupus nephritis. Ann Rheum Dis. 2012;

131. Hahn BH, McMahon MA, Wilkinson A, Wallace WD, Daikh DI, Fitzgerald JD, et al. American College of Rheumatology guidelines for screening, treatment, and management of lupus nephritis. Arthritis Care Res. 2012;

132. Hepburn AL, Narat S, Mason JC. The management of peripheral blood cytopenias in systemic lupus erythematosus. Rheumatology. 2010.

133. Pepper R, Griffith M, Kirwan C, Levy J, Taube D, Pusey C, et al. Rituximab is an effective treatment for lupus nephritis and allows a reduction in maintenance steroids. Nephrol Dial Transplant. 2009;

134. Tokunaga M, Saito K, Kawabata D, Imura Y, Fujii T, Nakayamada S, et al. Efficacy of rituximab (anti-CD20) for refractory systemic lupus erythematosus involving the central nervous system. Ann Rheum Dis. 2007;

135. Hofmann SC, Leandro MJ, Morris SD, Isenberg DA. Effects of rituximab-based B-cell depletion therapy on skin manifestations of lupus erythematosus - Report of 17 cases and review of the literature. Lupus. 2013.

136. Buch MH, Smolen JS, Betteridge N, Breedveld FC, Burmester G, Dörner T, et al. Updated consensus statement on the use of rituximab in patients with rheumatoid arthritis. Ann Rheum Dis. 2011; 
137. Makatsori M, Kiani-Alikhan S, Manson AL, Verma N, Leandro M, Gurugama NP, et al. Hypogammaglobulinaemia after rituximab treatment-incidence and outcomes. Qjm. 2014;107(10):821-8.

138. Bukhari $M$, on behalf of the BSR and BHPR Standards $G$ and AWG, Abernethy $R$, on behalf of the BSR and BHPR Standards G and AWG, Deighton C, on behalf of the BSR and BHPR Standards $G$ and AWG, et al. BSR and BHPR guidelines on the use of rituximab in rheumatoid arthritis. Rheumatology [Internet]. $2011 \mathrm{Dec}$ 1;50(12):2311-3. Available from: http://dx.doi.org/10.1093/rheumatology/ker106a

139. Van Gelder T, Berden JHM, Berger SP. To TDM or not to TDM in lupus nephritis patients treated with MMF? Nephrol Dial Transplant. 2015;

140. Marco H, Smith RM, Jones RB, Guerry MJ, Catapano F, Burns S, et al. The effect of rituximab therapy on immunoglobulin levels in patients with multisystem autoimmune disease. BMC Musculoskelet Disord. 2014;15(1):1-9.

141. Ramos-Casals M, Sanz I, Bosch X, Stone JH, Khamashta MA. B-cell-depleting therapy in systemic lupus erythematosus. Am J Med [Internet]. 2012 Apr;125(4):327-36. Available from: https://pubmed.ncbi.nlm.nih.gov/22444096

142. Furie R, Rovin BH, Houssiau F, Amoura Z, Santiago M, Contreras G, et al. OP0164 BLISS-LN: A RANDOMISED, DOUBLE-BLIND, PLACEBO-CONTROLLED PHASE 3 TRIAL OF INTRAVENOUS BELIMUMAB IN PATIENTS WITH ACTIVE LUPUS NEPHRITIS. Ann Rheum Dis [Internet]. 2020 Jun 1;79(Suppl 1):103 LP - 103. Available from:

http://ard.bmj.com/content/79/Suppl_1/103.abstract

143. GlaxoSmithKline. Efficacy and Safety of Belimumab in Black Race Patients With Systemic Lupus Erythematosus (SLE) (EMBRACE) NCT01632241. ClinicalTrials.gov [Internet]. 2012; Available from: https://clinicaltrials.gov/ct2/show/NCT01632241

144. Furie R, Aroca G, Alvarez A, Fragoso-Loyo H, Zuta Santillán E, Rovin B, Schindler T, Hassan I, Cascino M, Garg J MA. A Phase II Randomized, Double-Blind, Placebo-Controlled Study to Evaluate the Efficacy and Safety of Obinutuzumab or Placebo in Combination with Mycophenolate Mofetil in Patients with Active Class III or IV Lupus Nephritis [abstract]. Arthritis Rheumatol. 2019;71 (suppl.

145. Roche H-L. A Study To Evaluate The Efficacy And Safety Of Obinutuzumab In Patients With ISN/RPS 2003 Class III Or IV Lupus Nephritis (REGENCY) ClinicalTrials.gov Identifier: NCT04221477. 2020.

146. Liao AP, Salajegheh M, Morehouse C, Nazareno R, Jubin RG, Jallal B, et al. Human plasmacytoid dendritic cell accumulation amplifies their type 1 interferon production. Clin Immunol. 2010;

147. Alexander T, Sarfert R, Klotsche J, Kühl AA, Rubbert-Roth A, Lorenz HM, et al. The proteasome inhibitior bortezomib depletes plasma cells and ameliorates clinical manifestations of refractory systemic lupus erythematosus. Ann Rheum Dis. 2015;

148. Wallace DJ, Furie RA, Tanaka Y, Kalunian KC, Mosca M, Petri MA, et al. Baricitinib for systemic lupus erythematosus: a double-blind, randomised, placebo-controlled, phase 2 trial. Lancet. 2018; 
